\title{
Response to ACTH Challenge in Female Dairy Calves in Relation to Their Milk Yield
}

\author{
E. Szücs*, H. Fébel ${ }^{1}$, J. Janbaz, Gy. Huszenicza, M. Mézes, A. T. Tran, Cs. Ábrahám, A. Gáspárdy \\ I. Györkös ${ }^{1}$, J. Seenger and J. A. Nasser \\ Szent István University Gödöllő, H-2103 Gödöllő, Hungary
}

\begin{abstract}
Attempts have been made to establish relationship between the response to ACTH challenge in female calves, growth and first lactation performance. A total of 19 Holstein calves weighing $100 \mathrm{~kg}$ i. v. were given $0.50 \mathrm{IU}$ of ACTH $/ \mathrm{kg} \mathrm{BW}^{75}$ (EXACTHIN inj., Richter G., Budapest) at 60 days of age. Serial blood samples were taken at times 0, 0.5, 1, 2, 3, 4 and 5 hours and analyzed for cortisol, glucose insulin and FFA levels. From challenge series the area under the curve from time of administration and the following $5 \mathrm{~h}$ were calculated. Negative, and mostly loose relationship between response to ACTH challenge for cortisol, insulin, or FFA and ADWG during growth have been established $(\mathrm{p}>0.05)$ with positive one for glucose. Bivariate coefficients of correlation varied within the range from -0.35 to 0.15. Estimations reveal negative correlation between the length of first lactation and cortisol or insulin $(r=-0.80, p<0.001$ and $r=-0.45$, $\mathrm{p}<0.10$, resp.) Close association between cortisol or insulin and actual first lactation milk yield was found $(\mathrm{r}=-0.48, \mathrm{p}<0.10 ; \mathrm{r}=-0.64$, $\mathrm{p}<0.01$, resp.). Close relationship between the response to ACTH challenge and milk protein yield was present only for insulin ( $\mathrm{r}=-0.59$, p<0.05). (Asian-Aust. J. Anim. Sci. 2003. Vol 16, No. 6 : 806-812)
\end{abstract}

Key Words : ACTH Challenge, Response, Cortisol, FFA, Insulin, Glucose, Dairy Cattle

\section{INTRODUCTION}

Response of adrenal cortex including secretion of hormones is being modified by both acute and chronic stress. For evaluation standard adrenocorticotrop hormone application is recommended by several authors, i. e. Babena (1987), Beyersdorfer and Ender (1986), Broom (1988), Fisher et al., (1994), Mainati et al., (1990), Phillips et al., (1991), Redbo (1993), Veissier et al., (1988). The extent of physiological response can be influenced by several external and internal factors such as genetically determined susceptibility as it was suggested by Klemcke (1994) resulting in ambiguous conclusions in certain cases (Müller et al., 1986; Rushen, 1991). Ever since attempts have been made to evaluate the animals' ability in relation to traits of economic performance based on ACTH challenge test, even though the complexity of metabolic processes has not been taken into account yet (Lange and Lindemann, 1972). Despite of the fact that earlier studies referring to the description of the plasma corticoid response to ACTH in dairy cows (Gwazdauskas et al., 1972; Paape et al., 1974; Venkatasehu et al., 1970; Wegner et al., 1972) have been reported none of those studies attempted to correlate the response to ACTH with the animal's tolerance of stress. The first data on plasma adrenocorticoid response to corticotropin in dairy cattle were published by Smith et al., (1974).

\footnotetext{
* Corresponding Author: E. Szücs. Tel: +36-28-410200, Fax:+3628-410804, E-mail: szucse@fau.gau.hu

${ }^{1}$ Research Institute for Animal Breeding and Nutrition, H-2053, Hungary.

Received September 2, 2002; Accepted January 8, 2003
}

Although association of stress susceptibility and beef quality have already been established (Beyersdorfer and Ender, 1986; Szücs et al., 1995, 1996) only few results have been published in relation to dairy production concerning this issue (Babena, 1987).

For this reason, attempts have been made to establish relationship between the response to ACTH challenge in female calves, growth and first lactation performance in this study.

\section{MATERIALS AND METHODS}

\section{Experimental animals, ACTH challenge tests and blood sampling}

Due to earlier studies and experiences by Mézes et al. (1990) that reaction of juveniles to ACTH challenge test was higher than in mature counterparts, female dairy calves were chosen for experimentation. A total of 19 Holstein female calves weighing $100 \mathrm{~kg} \mathrm{i}$. v. were injected with $0.50 \mathrm{IU}$ of $\mathrm{ACTH} / \mathrm{kg} \mathrm{BW}^{.75}$ (EXACTHIN inj., Richter G., Budapest) using permanent cannula placed in the right jugular vein at 60 days of age. Serial blood samples were taken from vein into heparinized tube which were stored in crushed ice and then plasma was separated by centrifugation at $4{ }^{\circ} \mathrm{C}$ at $0,0.5,1,2$, 3,4 and $5 \mathrm{~h}$ and analyzed for cortisol, glucose, insulin and FFA levels as it had been described by Mézes et al. (1990) and Szücs et al. $(1995,1996)$.

\section{Laboratory analysis}

Samples were tested for (1) cortisol $\left({ }^{125}\right.$ I RIA, Isotope Research Institute of the Hungarian Academy of Sciences) using steroid free bovine serum for matrix, (2) glucose 


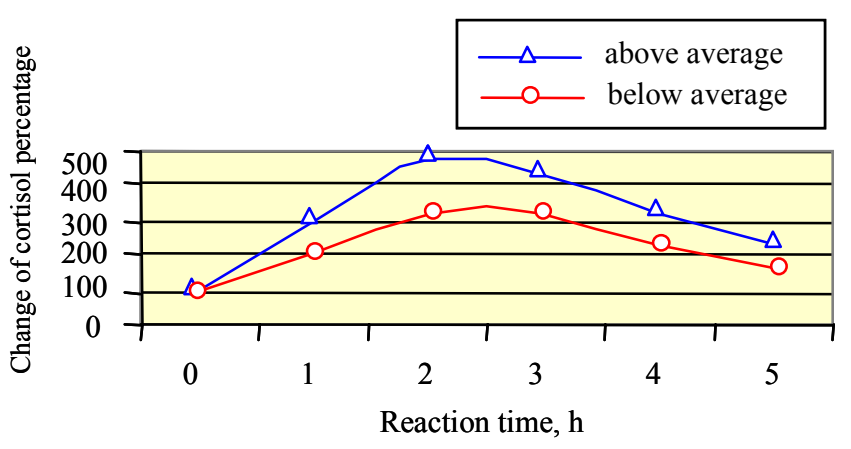

Figure 1. Relative response of serum cortison to ACTH challenge (base equals to pre test level, \%)

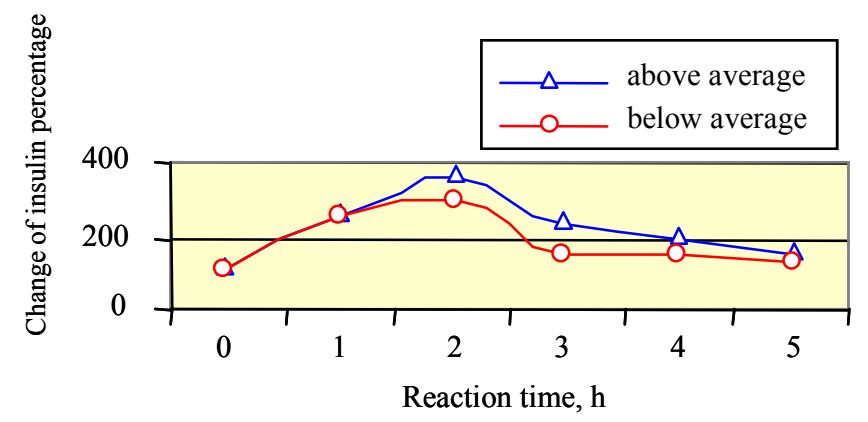

Figure 3. Relative response of serum insulin to ACTH challenge (base equals to pre-test levels, \%)

(GLUCO GOD/POD/PAP "GALENOPHARM" test developed by Trinder after adaptation to automated Eppendorf ACP 5040 analyzer for clinical diagnosis (Kerr, 1989), (3) insulin ( ${ }^{125}$ I RIA kits) and (4) free fatty acids-FFA (manual two phase colorimetric procedure by Noma et al., 1973). Response to ACTH challenge was evaluated by analyzing metabolic indicators in plasma in samples taken at different times after administration, the relative values in percentage of basal levels and areas under curve. In data processing the animals were assigned to one of the two groups based on their cortisol response, the first one for individuals above average $(n=9)$ and the other one for below average individuals $(n=10)$ assuming that higher response might be due to stress of elevated resistance and the lower one which may be associated to decreased resistance level.

\section{Growth and dairy performance}

Measurements recorded were (1) live weight (LW) for 7 day and 30 day intervals in calf rearing and heifer rearing period up to first delivery, (2) calculation of running average daily weight gain (ADWG); (3) after first delivery (4) days in milk, (5) actual full and part lactation performance for 100 days, (6) 305 days milk yields, (7) butterfat and (8) milk protein yields, as well as (9 and 10) percentage, (11) peak and (12) average daily milk yields,

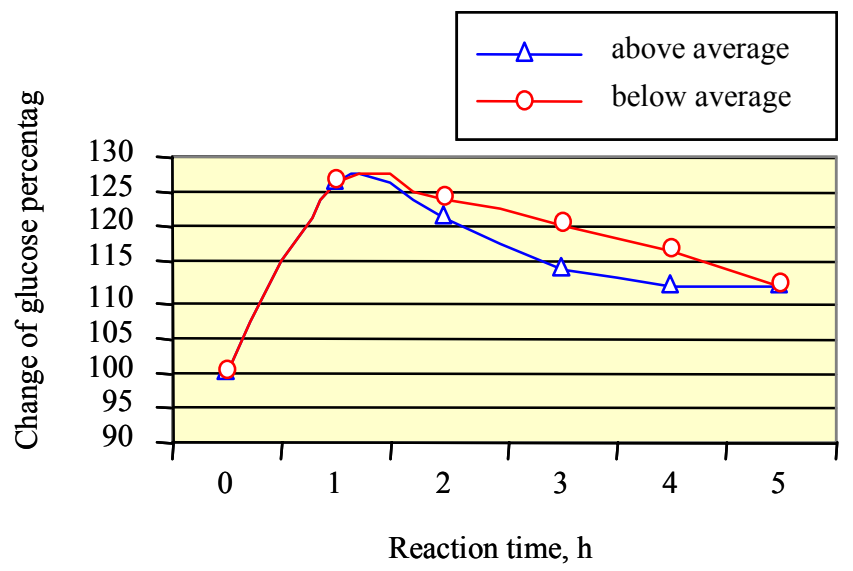

Figure 2. Relative response of serum glucose to ACTH challenege (base equals to pre-test levels)

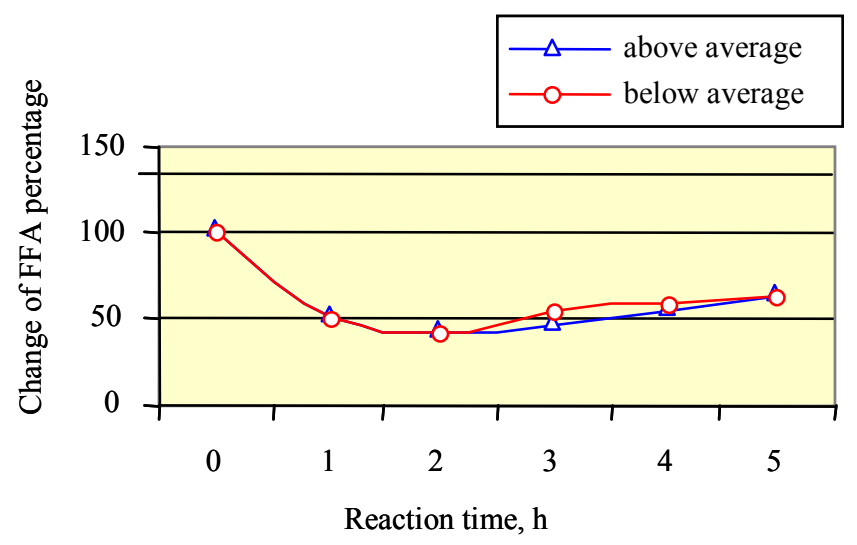

Figure 4. Relative response of serum FFA to ACTH challenge (base equals to pre-test levels, \%)

(13) persistency from the National Milk Recording Scheme (Hungary).

\section{Data processing and statistical analysis}

Data were analyzed using STATISTICA for Windows 4.5. (SatSoft Inc. USA, 1993) Program Package for calculation of basic statistics, that of statistical differences between means using t-Test and estimating bi- as well as multivariate coefficients of correlation. Findings were partly tabulated and demonstrated in Figures as percentage of basal values in case of metabolic parameters.

\section{RESULTS AND DISCUSSION}

\section{Physiological response}

Mean values and standard deviation of means for cortisol, glucose, insulin and FFA in blood samples taken prior to ACTH challenge test are presented in Table 1 for both groups assorted by above and below average response to high and low reaction in cortisol. Relative responses to 
Table 1. Average and standard deviation of physiological traits prior to ACTH challenge test

\begin{tabular}{|c|c|c|c|}
\hline \multirow[t]{2}{*}{ Item } & \multirow[t]{2}{*}{ Response } & \multicolumn{2}{|c|}{$\begin{array}{l}\text { Basic levels prior to } \\
\text { ACTH challenge test }\end{array}$} \\
\hline & & Mean & SD \\
\hline \multirow[t]{2}{*}{ Cortisol, mmol/1 } & above average $^{1}$ & 37.2 & 5.8 \\
\hline & below average ${ }^{2}$ & 39.0 & 5.8 \\
\hline \multirow[t]{2}{*}{ Glucose, $\mathrm{mmol} / \mathrm{l}$} & above average ${ }^{1}$ & 2.16 & 0.27 \\
\hline & below average ${ }^{2}$ & 2.11 & 0.20 \\
\hline \multirow[t]{2}{*}{ Insulin, $\mu \mathrm{U} / 1$} & above average $^{1}$ & 7.90 & 1.05 \\
\hline & below average ${ }^{2}$ & 7.80 & 0.10 \\
\hline \multirow[t]{2}{*}{ FFA, mmol/1 } & above average ${ }^{1}$ & 0.390 & 0.094 \\
\hline & below average ${ }^{2}$ & 0.346 & 0.071 \\
\hline
\end{tabular}

ACTH challenge as percentage of basal values are presented in Fig. 1-4 for cortisol, glucose, insulin and FFA, respectively. In "high" reaction calves peak values for cortisol were almost 5 times that of basal ones just prior to test. On the contrary, the increase in the "low" reaction group, it slightly exceeded only three fold that of basic level. The level of glucose had a linear ascending phase just after ACTH administration. Within $1 \mathrm{~h}$ it attained 1.3 times the levels of basal value, and showed gradual decrease thereafter. In both groups, the change seemed to follow almost similar tendency, even if the shape of "high" reaction calves followed a lower line. The insulin level attained 3.5 times level of basal value in "high" reaction animals and 3 times in "low" reaction ones with faster decline than it was the case for glucose. The consequence of rapid decrease may be associated with that of decline of glucose. Quick decline was recorded in FFA in relation to basal level, and the concentrations decreased to approximately half of that of base with slow increase thereafter in both groups.

It is a well known fact that the response of stress susceptible animals tend to be linked to their reaction ability to environmental load, a phenomenon which is generally defined by moderate activity level of the protection mechanism in the organism, called general adaptation

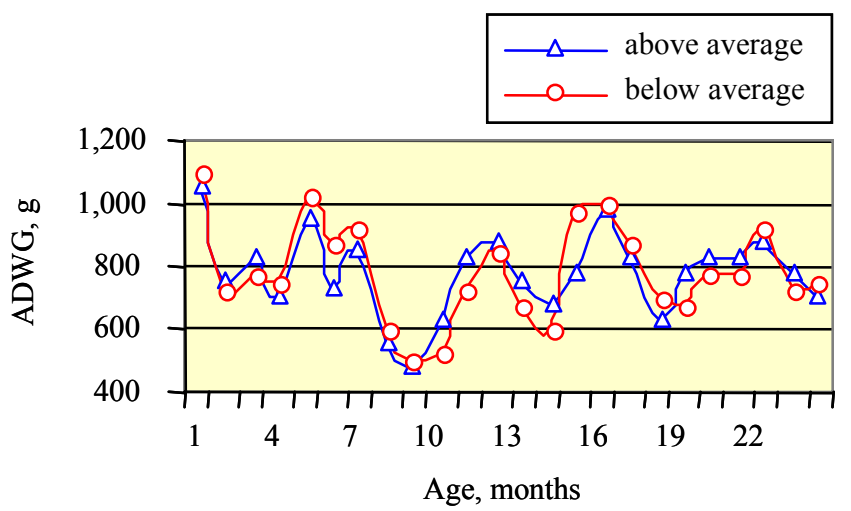

Figure 6. Change of average daily weight gain depending on the response to ACTH challenge test

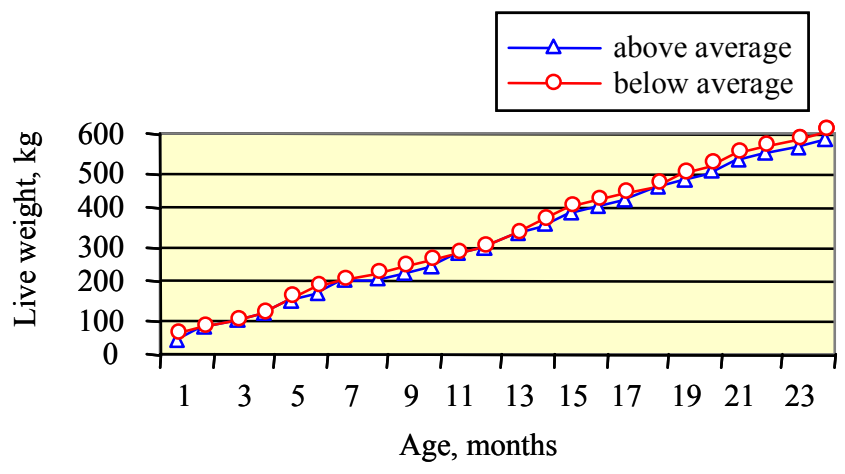

Figure 5. Live weight depending on the response to $\mathrm{ACTH}$ challenge test

syndrome (Selye, 1950). The general adaptation syndrome is characterized by reduced alarm reaction due to stress situations, where a short resistance is followed by fast exhaustion. The adrenal medulla produces adrenaline inducing fast adaptation with elevated plasma glucose levels, blood pressure, and tone of muscle and sensitivity of nerves. In adrenal cortex corticosteroids are discharged as an effect of adrenocorticotrop hormone induced by the corticotrophin releasing factor (CRF) which is associated with prolonged adaptation. Consequently, retarded growth, reduced viability and reproduction failures may occur. Out of the corticoids due to their catabolic effect of glucocorticoids (cortisone, corticosterone) the gluconeogenesis intensifies: glucose is produced from fat deposited and proteins. In the peripheries use of glucose and fat deposition are being reduced which may cause weak growth rate due to the antagonism of somatotropin and adrenal cortex hormones. Based on the statements outlined above worsened well-being, and reduced performance in terms of milk and meat production can be anticipated due to the consequences of stress situations.

\section{Growth and daily gain in raising of calves and juveniles}

Between the "high" and "low" reaction groups, no extreme differences were recorded for LW in either period of raising as shown in Fig. 5. Dynamics of ADWG seemed to follow similar tendencies as well, although marked influence is reflected due to phases of raising (Fig. 6). Change of peaks and steep descents seemed to follow a natural phenomenon mainly due to feeding regimes. Even if stresses including crowding may exert an adverse effect on growth rate and eating behavior as it has been established in our earlier study (Szücs et al., 1977), no differences were recorded between high and low reaction groups in this study. Findings do not seem to confirm conclusions by Fisher et al. (1994) using ACTH challenge to indicate consequences of increased social tension within animal groups, competitive behavior, number of interactions, change of physiological 
Table 2. Response of juveniles to ACTH challenge test in relation to dairy performance in first parity

\begin{tabular}{|c|c|c|c|c|c|}
\hline \multirow{3}{*}{ Item } & \multicolumn{4}{|c|}{ Response } & \multirow{3}{*}{$\mathrm{P}$} \\
\hline & \multicolumn{2}{|c|}{ Above average $(\mathrm{n}=9)$} & \multicolumn{2}{|c|}{ Below average $(n=10)$} & \\
\hline & Mean & SD & Mean & SD & \\
\hline Days in milk & 306 & 85 & 388 & 46 & $*$ \\
\hline Actual milk yield, $\mathrm{kg}$ & 8672 & 2977 & 8665 & 1085 & NS \\
\hline Actual butterfat yield, $\mathrm{kg}$ & 305.9 & 113.9 & 325.2 & 62.0 & NS \\
\hline Actual butterfat percentage, $\%$ & 3.50 & 0.19 & 3.75 & 0.50 & NS \\
\hline Actual milk protein yield, $\mathrm{kg}$ & 286.2 & 109.0 & 280.3 & 38.6 & NS \\
\hline Actual milk protein percentage, $\%$ & 3.29 & 0.29 & 3.23 & 0.16 & NS \\
\hline Peak milk yield per day, $\mathrm{kg}$ & 34.7 & 5.2 & 30.9 & 3.5 & NS \\
\hline Average daily milk yield, $\mathrm{kg}$ & 28.4 & 4.2 & 24.4 & 2.8 & $*$ \\
\hline Persistency & 77.8 & 3.0 & 80.3 & 6.8 & NS \\
\hline 305 day standard milk yield, $\mathrm{kg}$ & 8721 & 1626 & 7504 & 818 & NS \\
\hline 305 day standard butterfat yield, $\mathrm{kg}$ & 304.0 & 62.8 & 285.1 & 40.1 & NS \\
\hline 305 day standard butterfat percentage, $\%$ & 3.48 & 0.22 & 3.82 & 0.52 & NS \\
\hline 305 day standard milk protein yield, $\mathrm{kg}$ & 280.5 & 67.5 & 247.9 & 23.7 & NS \\
\hline 305 day standard milk protein percentage, $\%$ & 3.20 & 0.26 & 3.31 & 0.14 & NS \\
\hline 100 day milk yield, $\mathrm{kg}$ & 3065 & 446 & 2827 & 334 & NS \\
\hline 100 day butterfat yield, $\mathrm{kg}$ & 102.9 & 16.4 & 103.1 & 22.2 & NS \\
\hline 100 day butterfat percentage, $\%$ & 3.37 & 0.32 & 3.64 & 0.65 & NS \\
\hline 100 day milk protein yield, $\mathrm{kg}$ & 92.2 & 17.4 & 85.7 & 9.4 & NS \\
\hline 100 day milk protein percentage, $\%$ & 3.00 & 0.31 & 3.04 & 0.11 & NS \\
\hline
\end{tabular}

$\mathrm{NS}=\mathrm{p}>0.05$.

$*=\mathrm{p}<0.05$.

and/or health status. Stressors include factors in just the same yield in 10 months of lactation as their management such as handling, sorting, regrouping, counterparts of weak resistance to stresses and low transport, which may change the function of gastrointestinal adaptation ability for 12 months of lactation. However, it tract, nutrient absorption, partitioning of nutrients, and has to be emphasized that dairy traits of the former ones metabolism and may reduce feed intake, as well (Ingvartsen and Andresen, 1993). However, no change of live weight and/or growth rate due to low energy diets was recorded in young breeding bulls as Gábor et al. (1993) reported. The phenomenon may be associated with the "transition of tissues, the increase of muscle ratio" in the body. For this reason, as body weight remained unchanged increase of muscle tissue was suggested. Findings of this study seem to support this theory because of advantage of moderate rearing intensity in young dairy stock from the point of view of herdlife performance.

\section{Dairy performance}

In order to be able to establish differences due to response level to ACTH challenge first lactation performance has been also evaluated. Mean values and standard deviations are summarized in table 2. Even though findings clearly demonstrated the tendencies, statistical differences could be established only for two traits, days in milk and average daily milk yield in lactation $(\mathrm{p}<0.05)$. Stress resistant cows with increased response to ACTH challenge test tended to have shorter lactation's and produced higher amounts of milk per day in lactation than their counterparts with low reactions of increased days in milk and low average daily yields. These results support each other due to the fact that stress resistant cows produced showed wider range and increased standard deviations of means. Assuming similar genetic base the figures of 100 day part lactation and 305 day standard lactation reveal that the cows of high response, higher resistance to stresses and having better adaptation ability to eventual adverse environmental effects tend to produce higher milk yields in early lactation than their counterparts of low response and resistance and/or adaptation, the consequence of which may result in differences in efficiency and use of genetic capability. Findings are in accordance with a previously published study conducted by Flux et al. (1984) where various patterns of blood metabolites and hormones were associated with cows of different genetic merit. Insulin and glucose, particularly on low plane of nutrition, appears to be promising as indicators of high milk yield.

\section{Association of metabolic response to ACTH challenge with traits of economic importance}

Results of bi- and multivariate estimation of coefficients of correlation across response and performance traits are presented in table 3. Although rank order and close relationship among variables have been established in certain cases at high level of probability, results have to be interpreted carefully. On one hand, there is no doubt about marked and negative relationship between the cortisol response to ACTH challenge and days in milk, or insulin 
Table 3. Association among physiological response of juveniles to ACTH challenge test and dairy performance

\begin{tabular}{|c|c|c|c|c|c|c|}
\hline \multirow[t]{2}{*}{ Item } & \multicolumn{4}{|c|}{ Bivariate coefficients of correlation } & \multicolumn{2}{|c|}{$\begin{array}{c}\text { Multiple } \\
\text { correlation analysis }\end{array}$} \\
\hline & Cortisol & Glucose & Insulin & FFA & $\mathrm{R}$ & $\mathrm{R}^{2}$ \\
\hline \multicolumn{7}{|c|}{ ADWG in calf rearing period and prior to first service } \\
\hline From birth up to first service & -0.05 & -0.16 & -0.14 & -0.13 & 0.27 & 0.07 \\
\hline Milk feeding period & -0.20 & 0.10 & -0.30 & -0.34 & $0.52^{+}$ & 0.27 \\
\hline Post weaning period & -0.15 & 0.14 & -0.38 & -0.26 & $0.53^{+}$ & 0.28 \\
\hline Prior to first service & -0.26 & 0.15 & -0.16 & 0.09 & 0.29 & 0.09 \\
\hline \multicolumn{7}{|c|}{ Actual performance in the first parity } \\
\hline Days in milk & $-0.80 * * *$ & 0.33 & $-0.45^{+}$ & -0.19 & $0.87 * * *$ & 0.75 \\
\hline Milk yield & $-0.48^{+}$ & 0.36 & $-0.64 * *$ & -0.16 & $0.79^{* *}$ & 0.62 \\
\hline Butterfat yield & $-0.48^{+}$ & 0.31 & $-0.61^{*}$ & -0.17 & $0.75 * *$ & 0.57 \\
\hline Butterfat percentage & -0.35 & 0.15 & -0.27 & -0.03 & 0.38 & 0.15 \\
\hline Protein yield & -0.38 & 0.22 & $-0.59 *$ & -0.21 & $0.73 * *$ & 0.54 \\
\hline Protein percentage & 0.01 & -0.22 & -0.09 & -0.15 & 0.33 & 0.11 \\
\hline Peak milk yield per day & 0.20 & -0.22 & -0.22 & -0.02 & $0.52^{+}$ & 0.27 \\
\hline Average daily milk yield & 0.36 & -0.03 & -0.06 & -0.11 & $0.53^{+}$ & 0.28 \\
\hline Persistency & -0.19 & -0.10 & $0.42^{+}$ & 0.22 & $0.72^{* *}$ & 0.52 \\
\hline \multicolumn{7}{|c|}{ Performance adjusted for 305 days } \\
\hline Standard milk yield & 0.20 & 0.04 & $-0.46^{+}$ & -0.11 & $0.65^{* *}$ & 0.42 \\
\hline Standard butterfat yield & -0.04 & 0.09 & $-0.46^{+}$ & -0.15 & $0.59^{*}$ & 0.35 \\
\hline Standard butterfat percentage & -0.31 & 0.06 & -0.06 & -0.04 & 0.33 & 0.11 \\
\hline Standard protein yield & 0.04 & -0.003 & $-0.50^{+}$ & -0.15 & $0.64 * *$ & 0.41 \\
\hline Standard protein percentage & $-0.46^{+}$ & -0.04 & -0.24 & -0.11 & $0.50^{+}$ & 0.25 \\
\hline \multicolumn{7}{|c|}{ Performance in the first 100 days of lactation } \\
\hline Part milk yield & 0.15 & -0.16 & -0.17 & -0.31 & $0.52^{+}$ & 0.27 \\
\hline Part butterfat yield & -0.12 & -0.03 & -0.30 & -0.19 & 0.40 & 0.16 \\
\hline Part butterfat percentage & -0.27 & 0.10 & -0.26 & 0.01 & 0.30 & 0.09 \\
\hline Part protein yield & 0.14 & -0.35 & -0.02 & -0.37 & $0.53^{+}$ & 0.28 \\
\hline Part protein percentage & -0.01 & $-0.44^{+}$ & 0.23 & -0.22 & $0.54^{+}$ & 0.29 \\
\hline
\end{tabular}

and actual milk, butterfat and protein yield $(\mathrm{r}=-0.80$ $\mathrm{p}<0.001 ; \mathrm{r}=-0.64 \mathrm{p}<0.01 ; \mathrm{r}=-0.61 \mathrm{p}<0.05$ and $\mathrm{r}=-0.59$ $\mathrm{p}<0.05$, respectively), on the other hand intermediate relationships with approaching acceptable limits of statistical probability $(\mathrm{p}<0.10)$ were observed for cortisol response and actual milk and butterfat yield and standard protein percentage $(\mathrm{r}=-0.48$ and $\mathrm{r}=-0.046)$ or insulin response and days in milk, persistency, 305 day standard lactation milk, butterfat and protein yield (where order of coefficients varied between $\mathrm{r}=-0.42$ and $\mathrm{r}=-0.50$ range, yet, the associations seems to attain promising levels). Anticipation towards correlation of dairy traits to glucose or FFA response concerning ACTH challenge test may be of limited value. Babena (1987) published similar results. In the study cited the degree of adaptability to changing environment was estimated by challenging with ACTH administration in dairy cows. The correlation of standard deviation of daily milk yield after ACTH (with $\mathrm{r}=0.92$ and $\mathrm{r}=0.60$ for strongly and poorly responding cows, respectively) with lactation milk yield attained 0.53 $(p<0.01)$. The correlation of 11-oxycorticosteroid concentration with lactation milk yield was $0.37(\mathrm{p}<0.01)$ and with the standard deviation of daily milk yield it was $0.44(p<0.01)$.

On the contrary, if the relation system of metabolic response to ACTH challenge and dairy traits of economic importance was evaluated by multiple correlation analysis (Table 3) the expectations are promising. Multiple coefficients of correlation were within the range of 0.59 0.89 at high level of probability $(\mathrm{p}<0.001$ and $\mathrm{p}<0.05)$. Findings may prompt the need for integrated and complex application of physiological response of selected variables. Consequently, forecast of the animals' performance level might be estimated based on coefficients of determination at high level of probability. This statement can be supported by the coefficients of determination the range of which varied 0.35 and 0.75 in this study. Based on this, a simple dynamic model of metabolism was recommended by France at al. (1987) for growing beef cattle. The scheme is based on carbon and nitrogen fluxes. The blood metabolite variables were acetyl-coenzyme A equivalents, glucose equivalent and amino acids, and the body composition were 
ash, lipid and protein. The fluxes in the model were based on biochemical transactions, 6 of that were catabolic and 3 biosynthetic ones. The development of a model like this should be taken into consideration for dairy cows, as well.

\section{CONCLUSIONS}

As far as response to ACTH challenge is concerned, in "high" reaction calves peak values for cortisol were almost 5 times that of basal ones, while they slightly exceeded only three fold the basic level in the "low" reaction group. The level of glucose had a straight ascending phase just after ACTH administration and within 1 hour it attained 1.3 times the basal value. In both groups, the shape of change seemed to follow almost similar tendency, even if the shape of "high" reaction calves followed a lower line. The insulin level attained 3.5 times level of basal value in "high" reaction animals and 3 times height of "low" reaction ones with faster decline than it was the case for glucose. Quick decline was recorded in FFA in relation to basal level in both groups.

In terms of $\mathrm{LW}$ and/or ADWG no extreme differences were recorded between the "high" and "low" reaction groups, in either period of raising. Change of peaks and steep descents might mainly be due to feeding regimes applied. Findings on dairy records reveal that the cows with high response, higher resistance to stresses and having better adaptation tend to produce higher milk yields in early lactation than their counterparts of low response and resistance and/or adaptation, the consequence of which may result in differences in efficient use of their genetic ability.

Summing up the results of this research, the findings reveal correlation between the metabolic response of animals to ACTH challenge and traits of economic importance. Thus, negative, and mostly loose relationship between response to ACTH challenge for cortisol, insulin, or FFA and ADWG during growth have been established $(p>0.05)$ with positive one for glucose. Bivariate coefficients of correlation varied within the range from $\mathrm{r}=-0.35$ to 0.15 . Estimations reveal negative correlation between the length of first lactation and cortisol or insulin $(\mathrm{r}=-0.80, \mathrm{p}<0.001$ and $\mathrm{r}=-0.45, \mathrm{p}<0.10$, respectively). Close association between cortisol and insulin and actual first lactation milk yield was found $(\mathrm{r}=-0.48, \mathrm{p}<0.10 ; \mathrm{r}=-0.64, \mathrm{p}<0.01$, respectively). Close relationship between the response to ACTH challenge and milk protein yield was present only for insulin $(r=-0.59, p<0.05)$. If the relation system in attempts to approach the association of metabolic response to ACTH challenge and dairy traits of economic importance the expectations for multiple correlation analysis may be promising.

In their dynamic change multiple coefficients of correlation may prompt the need for integrated and complex application of physiological response of selected variables. Forecast of the animals' performance level can be estimated based on coefficients of determination at high level of probability.

\section{REFERENCES}

Babena, V. V. 1987. Milk production and adaptability in heifers. Nauchn. osn. Rasv. Zhivotn. v BSSR. 17:62-64.

Beyersdorfer, G., K. Ender. 1987. Der ACTH-Belastungstest, ein möglicher Parameter zur Quantifizierung der Belastbarkeit. Arch. f. Tierz. 29:397-403.

Broom, D. 1988. The scientific assessment of animal welfare. Appl. Anim. Behav. Sci. 20:5-19.

Fisher, A. D., W. J. Enright, D. J. Prendiville, F. H. Austin. 1994. Effect of space allowance on the production, behavior and adrenal response of finishing beef heifers in group-housed pens. 45th Ann. Meet. EAAP, Edinburgh, Scotland, UK, 5-8 September 1994

Flux, D. S., D. D. S. Mackenzie, G. F. Wilson. 1984. Plasma metabolite and hormone concentrations in Friesian cows of differing genetic merit measured at two feeding levels. Anim. Prod. 38:377-358.

France, J., M. Gill, J. H. M. Thornley, P. England. 1987. A model of nutrient utilization and body composition in beef cattle. Anim. Prod. 44:371-358.

Gábor, Gy. S. Bozó, M. Mézes, P. Ribiczené Szabó. 1993. Az energiahiányos takarmányozás hatása a tenyészbikák anyagcseréjére. 1. közlemény: Fehérje-, zsír-és szénhidrátanyagcsere. Állatteny. és Tak. 42:337-347.

Gwazdauskas, F. C., W. W. Thatcher and C. J. Wilcox. 1972. Adrenocortocotropin alteration of bovine peripheral plasma concentrations of cortisol, corticosterone, and progesterone. J. Dairy Sci. 53:1165-1169.

Ingvartsen, K. L., H. R. Andresen. 1993. Space allowance and type of housing for growing cattle. Acta Agric. Scand., Section A., Anim. Sci. 43:65-80

Kerr, M. G. 1989. Veterinary Laboratory Medicine, Blackwell Sci. Publ., Oxford Klemcke, H. G. 1994. Responses of porcine pituitary-adrenal axis to chronic intermittent stressor. Dom. Anim. Endocrin. 11:133-149.

Lange, W., E. Lindenmann. 1972. Untersuchungen über die Nebennierenfunktion bei Mastrindern verschiedener Genotypen. Arch. f. Tierz. 15:171.

Maianti, M. G., G. Bertoni, R. Lombardelli, V. Cappa. 1990. Variazioni ematiche in bovine sottoposte a fattori diversi di stress. Zoot. Nutr. Anim. 16:9-27.

Mézes, M. Zs. Bárándi, E. Szűcs, I. Ács. 1990. Növendék hízóbikák adrenokortikális aktivitásának vizsgálata ACTH-terhelési teszttel. Magyar Élettani Társaság LV. Vándorgyülése. Budapest, 1990. július 4- 6 .

Müller, C.; J. Ladewig, M. C. Schlichting, H. H. Thielscher, D. Smidt. 1986. Behavioral and ethological criteria for assessing possible stress factors arising from flooring and density of heifers in group housing. KTBL-Schrift. 311:37-47.

Noma, A., H. M. Okabe, M. Kita. 1973. A new colorimetric microdetermination of free fatty acids in serum. Cl. Chim. Acta. 43:317-320.

Paape, M. J., D. W. Carrol, A. J. Kral, R. H. Miller, C. Desjardins. 
1974. Corticosteroids, circulating leucocytes and erythrocytes in cattlle: Diurnal changes and effect of bacteriologic status, stage of lactation and milk yield on response to adrenocorticotropin. Am. J. Vet. Res. 35:355.

Phillips, W. A., P. E. Junewicz, D. L. von Tungeln. 1991. The effect of fasting, transit plus fasting, and administration of adrenocorticotropic hormone on the source and amount of weight lost by feeder steers of different ages. J. Dairy Sci. 69:2342-2348.

Redbo, I. 1993. Stereotypes and cortisol secretion in heifers subjected to tethering. Appl. Anim. Behav. Sci. 38:213-225.

Rushen, J. 1991. Problems associated with the interpretation of physiological data in the assessment of animal welfare. Appl. Anim. Behav. Sci. 28:381-386.

Selye, J. 1950. The physiology and pathology of exposure to stress. Acta Inc. Montreal

Smith, R. D., W. Hansel. C. E. Coppock. 1974. Plasma adrenocorticoid response to corticotropin in dairy cattle fed high silage diets. J. Dairy Sci. 58:1708-1712.

Szücs, E., I. Molnár, I. Török. 1977. Az egy állatra jutó alapterület és a csoportnagyság együttes hatása a növendék-bikák hízlalási eredményeire és viselkedésére. Állatteny. 26:31-37.
Szücs, E., M. Mézes, I. Ács, Zs. Bárándi, A. T. Tran, M. Ábrahám. 1995. Vizsgálatok a szarvasmarha hústermelése és stresszérzékenysége közötti összefüggéshez. Állatteny. és Takarm. 44:211-225.

Szűcs, E., M. Mézes, I. Ács, Zs. Bárándi, A. T. Tran, M. Ábrahám. 1996. Relationship of meat production characteristics to stress susceptibility in young bulls. Arch. f. Tierz. 39:129-142.

Veissier, I., P. Neindre, P. Le-Neindre. 1988. Cortisol responses to physical and pharmacological stimuli in heifers. Repr., Nutr. Dev. 28(3A):553-562.

Venkataseshu, G. K. and V. L. Estergreen. 1970. Cortisol and corticosterone in bovine plasma and the effect of adrenocorticotropin. J. Dairy Sci. 53:480.

Wegner, T. N. and G. H. Stott. 1972. Serum minerals, leukocyte profiles, and plasma corticoids in dairy heifers after an injection of corticotropin. J. Dairy Sci. 55:1464. STATISTICA for Windows. 1993. Release 4.5. StatSoft, In., USA. 